\title{
TUITION REFORM IN CHINESE HIGHER EDUCATION
}

\author{
XIN LI \\ UNIVERSITY OF SASKATCHEWAN
}

\section{ABSTRACT:}

This paper discusses the new trend in Chinese higher education reform -tuition reform. To meet the needs of the new market economy which was started in the early 1980s, Chinese higher education is abandoning the old free tuition system. This paper provides a historical review of the tuition system in Chinese higher education by examining the no historical periods: the planned economy period and the market-oriented economy period. An analysis of the 1995 ruition reform is given by using two analytical frameworks: State-centred and citizen-centred frameworks. The paper also discusses the contradiction between the tuition reform and some current policies, and the impact of the tuition reform on Chinese youth's ideas, on higher education, on primary education, and on secondary education.

Since the early 1980s, China has been carrying out a market-oriented economic reform program. Chinese higher education has experienced a wide-range of reform as well. Tuition reform is an important part in the overall reform of the Chinese higher education system. The 1995 tuition reform marks a breakthrough in the overall reform in Chinese higher education. This paper elaborates some insights about the tuition reform by a discussion of the historical background of the tuition system, the policy-making issues using the State-centred and citizencentred frameworks, a critical analysis of the contradiction between the tuition reform and some current policies, and the impact of the tuition reform.

\section{PLANNED ECONOMY PERIOD (1949-1979)}

After the founding of the People's Republic of China in 1949, China began to develop its economy after the Soviet Model -- "a centralized, socialist, planned economy." Under this planned economic system, all economic activities in the country were arranged and operated according to a centralized five-year plan with detailed annual plans. All factories and businesses arranged their production, business and services according to the national plan. Human resources supply for each economic sector was an important element in the national plan. 
The human resources plan ensured the proper staffing of each economic sector.

In China, higher education was planned under this economic system. A key object of the higher education system was to meet the needs of the national economic development. "Higher education institutions were very responsive to manpower requirements and were designed totally according to the stratified manpower needs" (Cheng, 1995, p. 199). The enrollment of students in each university and graduates' job assignments following completion of degree and certificates were implemented strictly according to the preset national plan. Each year, the number of students to be enrolled matched the planned vacancies of the job assignments four years later. Upon graduation, the university graduates were assigned a job in the Stateowned academic, economic or governmental agencies based on the manpower plans. For example, if the national plan required 1,000 additional ship building engineers four years later, the universities and colleges all over the country were directed to admit 1,000 students majoring in ship building engineering. Four years later when these students graduated, each would be assigned a job as a ship building engineer in a State-owned enterprise.

Along with this planned economy, a free tuition structure was established in Chinese higher education. All students admitted to institutions of higher learning had access to free tuition and accommodation, and were free of other fees. The State paid the tuition and other fees for the university students, and the students were guaranteed a job assignment after graduation. During the period of the planned economy (1949-1979) this "practice guaranteed the supply of qualified personnel" needed by the country (Ling, 1993, p. 18).

\section{PLANNED-MARKET ECONOMY TRANSITION PERIOD (1980-)}

The 1980s saw the transition of the planned economy to the "socialist market" economy in China. The planned economy, once regarded as the cornerstone of socialism, lost its dominance in China and was replaced by the "market economy." "The state has put into practice a socialist market economy" was formally written into the Constitution of the People's Republic of China in March, 1993 (Chen, 1993, p. 14). The new economic system was described as "placing the market mechanism in a key position to distribute all social resources," and under this system, the government would no longer interfere with enterprise operations (Beijing Review, 1992a, p. 7). Since then, the establishment of a market 
economy has become the focus for economic restructuring, and the national economy is no longer controlled by the national plan, but by the market itself. Just as in the commodity market, the talent market is quite flexible and changeable. In the market economy the State cannot foresee the condition of the job market four years later, and is often unable to assign jobs for most graduates upon their graduation.

To deal with the new situation and to meet the need of the new market economy, an overall higher education reform took place. Tuition restructuring was a part of the reform process. Tuition reform on a small scale in Chinese higher education started in the mid-1980s. In 1985, the State Education Commission (SEC) initiated an experimental revenue generation program in higher education institutions called the "contract-study" program (Weituo Daipei). In this program, universities and colleges admitted students sent by their future employers (work units), who paid the full tuition and other fees during the students' study in the universities and colleges. After graduation the students were committed to working for the work units. Although through a different channel, the tuition, in fact, was still paid by the State, because almost all of the work units were State-owned enterprises. As the Chinese say, "the wool still comes from the sheep's back." However, this was the first time that Chinese higher education institutions charged tuition since 1949. In the 1992 fall semester, among the 720,000 freshmen in Chinese universities and colleges, there were about 50,000 students in the "contract-study" program (Beijing Review, 1992b, p. 7).

In 1986, this experimental program was extended to allow universities and colleges to accept a small number (three to five percent of the freshmen enrollment) of self-sponsoring students (Zifei Sheng). Law (1995) pointed out that the number of these privately financed students increased rapidly from 1,030 ( 0.18 percent of the total tertiary student population) in 1986 to 86,300 (11.4 percent) in 1992 (p. 331). According to Chinese sources, in 1992, approximately 100,000 students, or nearly 15 percent of the total freshmen, selffinanced their higher education (Beijing Review, 1992, p. 6). In 1993, the upper limit of self-sponsoring students was increased to 25 percent of the total freshmen enrollment, but the supply of places still fell short of demand (An, 1994, p. 14). These students paid the tuition and fees in full all by themselves, and the State no longer committed to assigning them jobs after graduation. In this sense, they were the first generation of the true self-supporting higher education receivers in the history of the People's Republic. 
Along with these experimental programs, a new fee policy was introduced in 1989. The Chinese universities and colleges, for the first time since 1949, began to charge the miscellaneous fees (Xuezafei) on the entire student population. By 1993, these miscellaneous fees paid by university and college students ranged from 200 yuan to 400 yuan (RMB) 1 per academic year.

A new milestone of the tuition reform in Chinese higher education was met in 1995. The State Education Commission (SEC) decided to implement tuition reform on a larger scale and to gradually abolish the old, free tuition system by the year 2000. In the new school year, starting from September, 1995, over 200 universities and colleges (about 20 percent of all institutions of higher learning in China) charged tuition of 1,000 to 2,000 yuan (RMB) and additional miscellaneous fees on all students. "According to the Commission, most colleges and universities will introduce the new system by 1997, with all having done so by the year 2000" (Zhou, 1995, p. 15).

After one year's implementation of the new tuition system in 257 universities and colleges, SEC decided to speed up the reform and announced that more than half of the universities and colleges in China will adopt the new tuition system in the 1996 fall semester, and the free tuition system will be completely abolished in Chinese higher education from the 1997 fall semester (Lianhe Zaobao, 1996). In fact, Shanghai city is already taking the lead in the tuition reform. The Education Commission of Shanghai announced that Shanghai would abolish the free tuition system beginning with the 1996 fall semester and charge tuition of 2,500 to 3,000 yuan (RMB) on every new university entrant (Xu, 1996).

\section{FRAMEWORK ANALYSIS OF THE TUITION REFORM POLICY}

The implementation of the tuition reform is analyzed within two analytical frameworks: State-centred and citizen-centred. The Statecentred framework deals with the decision to gradually abolish the free tuition system. The citizen-centred framework discusses the effects the new tuition system has on the Chinese people.

\section{STATE-CENTRED Framework}

The free tuition system was the product of the planned economic system. Free tuition represented a contract between the students and the State. The nature of the contract was that the State paid the tuition 
for the students and, in turn, the students worked for the State after graduation. The free tuition system was established based on the premises that (1) the graduates would be granted a job assignment; and (2) the graduates would serve the State-owned enterprises and governmental agencies. Following China's transition to a modified market economic system, these premises could no longer be realized. First, the preset national plan often failed to meet the changeable needs of the talent market. In addition, with the development of a market economy, the national plan no longer held a monopoly in job assignment, so the State could not guarantee a job assignment for most of the graduates nor the supply of suitably trained candidates for openings in State-controlled industry and bureaucracy.

Second, with the development of the market economy, the proportion of non State-owned sectors in the national economy increased rapidly and outside of State control. By 1992, estimates placed fifty-seven percent of the total number of employees (excluding agricultural labourers) in China worked in non-State-owned enterprises (Gao, 1994, p. 15). Most of the enterprises are Sino-foreign joint ventures, foreign ventures, and collective or private businesses. They play an ever-more important role in the national economy and every year employ many university graduates, including university graduates who received free tuition higher education from the State-owned universities and colleges. It is therefore reasonable that these non-State sectors should contribute to the training of the qualified personnel they need. Since the State could neither guarantee a job for the graduates nor could all of the graduates serve the State-owned enterprises, there is no need nor is feasible for the State to provide free tuition higher education.

Although China is committed to rapid development of its economy through market forces, it remains a developing country and the educational expenditure is very low compared with other countries in the world. Out of 149 nations surveyed by the UNESCO in the late 1980s, China ranked 130th in the proportion of GNP that it allocated for education. From some perspectives, this picture becomes more gloomy when the 1.1 billion population is taken into account. In China, per capita educational spending is about 40 yuan (RMB) a year, which ranks next to the last in the world (Ma, 1992, p. 14). In 1991, the total public expenditure on education in China as a percentage of GNP was 2.3 percent which is less than the median percentage -- 4.1 percent -. of developing countries (UNESCO, 1993, p. 104).

In March, 1993, the State Council issued the Program for China's Educational Reform and Development in which the percentage of 
educational expenditure to GNP is projected to reach four percent by the end of this century (Cui, 1993, p. 17). Even with such an increase in expenditures, the Chinese educational needs will remain unmet and unsatisfied. The school facilities need to be improved, the teaching technology needs to be updated, and most importantly, the faculty salaries need to be increased.

At the level of higher education institutions, funding shortage is a serious problem. The free tuition higher education system placed a heavy burden on the State and made the problem of educational funding even more serious. In general, Chinese universities and colleges are still "in poverty." Most universities and colleges "do not get the fund adequate to cover their expenditures and the net results are miserable salaries, appalling physical environments and low morale" (Cheng. 1995, p. 203). "As early as the period between 1986 and 1989, the financial deficits of Chinese higher education institutions had reached 20-30 percent" (Yin and White, 1994, p. 222). In recent years, the lack of financial resources in many Chinese higher education institutions was often up to one-third to one-half of their recurrent costs (Yang, 1993, p. 11). Peking University's yearly funding shortfall is around 10 million yuan (RMB). Beijing No. 2 Foreign Languages Institute spent nearly 10 million yuan (RMB) in 1992, but the State's allocation was only seven million (An, 1994, p. 14).

Under the free tuition system, the more students higher education institutions admitted, the heavier burden the State had to bear. Since 1978, the higher education enrollment has increased greatly. In 1994, Chinese universities and colleges admitted 899,800 and $2,798,600$ new students in the three-year and four-year undergraduate programs, 2.24 and 3.27 times greater respectively than 1978 (Gao, 1995). Therefore, a great financial burden was placed on the State, so the further development of Chinese higher education was hindered by the funding shortage. Charging tuition and fees may, to some degree, lighten the financial tension in higher education institutions. According to Zhou (1995), the State spends between 8,000 to 10,000 yuan (RMB) per year for each university and college student, and the current tuition will cover 10 to 20 percent of these expenses (p. 17). This means the universities and colleges can at least get a 10 to 20 percent increase in their revenue by charging tuition. This increase is significant compared with the national educational investment.

There is an accepted notion in the world that higher education is not compulsory education. Higher education should provide equal opportunity for every individual, but unlike compulsory education, not 
all individuals are qualified to enter institutions of higher learning. Because of the space limit in higher education institutions, not all qualified applicants can be admitted. Furthermore, it is the students themselves who make the decision of whether or not to attend university. "According to generally accepted international practices, non-compulsory education requires that students pay tuition. This factor conforms with the law governing the development of education" (Zhou, 1995, p. 16). Even in the highly developed countries like the United States and Canada, higher education is not provided free to all qualified citizens. For example, in the United States, compulsory education $(\mathrm{K}-12)$ is completely free. Students not only enjoy free tuition but also free textbooks and free meals. American higher education, however, charges exceptionally high tuition. In China, compulsory education ( 1.9 equivalent) is not as "free" as in the United States. Students have to pay some fees and buy their own textbooks. For a developing country like China, it is reasonable that tuition is taken as part of the basic entrance requirement of higher education institutions. In this sense, charging tuition for higher education is fair to both those who are receiving higher education and those who are not.

\section{CTtZEn-Centred Framework}

Higher education benefits both individuals and society in economic and non-economic forms. Individuals may benefit by getting better jobs and higher lifetime earnings, by having more satisfying family lives, by adding richer cultural and civic dimensions, and by a greater sense of participation in the surrounding world. The society at large may benefit from higher production and better living standards, from an enlarged supply of effective leadership at every level, and from the enrichment of its culture through the release of greater creativity in more people. (Coombs and Hallak, 1987, p. 8) Higher education provides a higher level of professional education, through which the educated acquire certain professional knowledge and abilities which they can enjoy all through their life. To some degree, higher education is the individual's investment for a better quality of life.

According to research conducted by the Carnegie Commission on Higher Education, the rates of return on the investment (ROI) in higher education in the form of earnings vary with countries and years. In America, baccalaureate attainment can get as high as ten percent return on the investment (The Carnegie Commission on Higher Education, 1973, p. 72). In China, the ROI is much higher to graduates from higher 
education institutions, because there are relatively fewer people who obtained higher education. In 1982, among youths aged 15 years or more, only one percent of males and 0.3 percent of females obtained post-secondary education (Rai, 1991, p. 39). University graduates are paid more money than high school graduates. Since individuals are one of the beneficiaries of higher education, they should pay their share in the form of tuition. In some developed countries, such as the United States, Japan and Germany, the individuals contribute forty percent of the higher education expenses, and in such developing countries like India and Brazil, the individual's share in higher education expenses is as high as twenty-five percent. At this time, the Chinese individual's investment in higher education expenses is only seven percent (An, 1994, p. 14).

Because of the more than forty year practice of free tuition for higher education, most Chinese people think that tuition should be paid by the State. This idea might not have been incorrect during the planned economy period. However, with the development of the marketoriented economy, it may be necessary for Chinese citizen to develop a new attitude toward financing higher education. As beneficiaries, they may be expected to contribute significantly more to their higher education than they had in the past.

Yet for citizens, the cost of tuition 1,000 to 2,000 yuan (RMB) yearly is a large sum for ordinary Chinese families, especially for the rural residents. Chinese rural residents will be the greatest victims in the new tuition system with the doors to higher education institutions closed to their children because of the high tuition. Although the rural economy has been expanded significantly since 1978, the economic gap between urban and rural areas is still remarkably great. The 1993 percapita net income of Chinese rural residents was only 922 yuan (RMB) per year while the urban residents' average income reached $2,336.5$ yuan (RMB) (Beijing Review, 1995, p. 18). Hence a tuition of 2,000 yuan is prohibitive for most of the poor farmers' children. For example, Jiang Yongtao, a poor farmer's son in Shandong Province, was admitted by Guangdong University of Chinese Medicine and Pharmacy in the 1995 fall semester. He ranked the first in the National University Entrance Examination scores among those admitted to the university. He found that it was impossible for his family to pay the tuition and fees for his five years' study, so he left the university and went back home after only one day's stay on the campus (Zhen, 1995) ${ }^{2}$. Another case, revealed by the Chinese press in 1993, showed that "a candidate from a mountainous area in south Ningxia Hui Autonomous Region 
passed the entrance examination of a university in Xian, Shaanxi Province, but failed in his ambition to go there as the fees amounted to what was an astronomical figure of 2,000 yuan for him" (Guangming Daily, 1993). According to recent statistics, poor students account for 20 percent of the total higher education enrollment, while the exceptionally poor students account for 10 percent of the total enrollment ( $Y$ in and $\mathrm{Bi}, 1995$ ). It is estimated that by the year 2000 the tuition for four years' university study will be as much as 30,000 yuan (RMB) (China's Scholars Abroad, 1996). Thus, for the ordinary urban Chinese families it will be a heavy burden to support a university student, not to mention the poor rural families.

In short, while the Chinese citizens should pay tuition for their higher education, because they are the main beneficiary of higher education, many of the farmers and some urban residents are too poor to pay for their children's tuition. How to ensure the qualified poor farmer's children have equal opportunity to enter university should be a great concern in the tuition reform.

\section{CONTRADICTION BETWEEN THE TUITION REFORM AND SOME CURRENT POLICIES}

The implementation of the new tuition system is in conflict with some current policies of Chinese higher education. The first conflict is with the policy of school year system in higher education. We know that most of the institutions of higher learning in the world have adopted the credit system. After the students complete a certain amount of credit units within a certain length of time, they receive their degrees. The flexibility of the credit system makes it possible for students to work for their degrees either full time or part time. But Chinese universities and colleges use a school year system, under which students are assigned to a class of twenty to thirty students. All the students in the class study in a unified course program. They have to take the same courses during their study and complete their study at the same time. A regular bachelor's degree requires four years' full time study, and a technical diploma requires two to three years' full time study. From 1985, "only a limited form of the credit system was adopted" (Hayhoe, 1989, p. 71), and few universities and colleges have completely adopted the credit system. Along with the tuition reform, Chinese universities began to provide some forms of financial assistance for students; for example, scholarship, loans and grants. Because of the funding limits, not all students in need can get financial 
support. Based on the western countries' experience, students can do part-time work and part-time study, or take work-study programs in order to support themselves during their studies in the university.

The current school year system in Chinese higher education institutions actually eliminates the possibility of part-time study. Under this system, the part-time work and part-time study or workstudy program is only an imaginary idea, and is difficult to put into practice. Full time study makes it impossible for students to make extra money to support themselves. In short, the school year system in Chinese higher education matches the free tuition system because the students do not need to work to support their studies when the tuition is free. But the school year system does not work well with the new tuition system if the students plan to work part-time and to study part-time. With the operation of the new tuition system, some changes must be made in the school year system in order to provide the opportunity of part-time study for the students in need.

The second conflict is with decisions made by students and universities about curriculum matters. When students pay their own tuition for their higher education, they are sure to carefully select their fields of study. It is understood that the program the students take in university is a vital factor in job hunting after graduation. For example, a bachelor's degree in business administration, accounting or computer science is much more competitive in the labor market than a degree in Chinese language, history or physics. The former degree holders can easily find much better paid jobs than the latter degree holders. Since everybody wants to make best use of their money, the well-paid job-related programs have become the focus of students choice of study in the universities and colleges. To meet this need, the higher education institutions have to redesign the courses offered and make some reforms in curriculum. But this is easier said than done. The administration of Chinese higher education is a highly centralized bureaucratic system. Curricular decision making power is centralized in the State Education Commission (SEC), the headquarters of Chinese educational administration ( $W u$ and $Y$ ang, 1989, p.348). All curriculum and specialties offered in Chinese universities and colleges must be approved by the SEC. This situation makes bottom-up curriculum reform difficult. However, to implement the new tuition system, curriculum reform is needed. In turn, to make reforms in curriculum, decentralization of power is needed. In this sense, the implementation of the new tuition system needs the in-step reform in other fields in the Chinese higher education system. 


\section{IMPACT OF THE TUITION REFORM}

First, the university tuition fee exerts a heavy burden on the low income Chinese people, but Chinese youth for the first time in the history of the People's Republic are given the right to choose -- to choose an education and to choose $a$ job. Their individual needs and individual choices are recognized publicly. In this sense, the tuition reform is a kind of social progress. This progress is especially significant for the Chinese people, because they are given the chance for academic and vocational self-actualization. "For the first time in the socialist society, young adults are given the liberty to exercise their individual choices rather than suppressing their individual desires" (Cheng, 1994, p. 68). In the past, "the notions of individual needs and individual choices which are so fundamental to educational ideas in the west wert simply absent in China" (Cheng, 1994, p.69). The Chinese youth's individual needs and choices were bound to the national needs. The most popular motto among young students was that "the national need is my need and the nation's selection is my choice." Once the long suppressed individual desires are liberated, they will release great power in the form of creativity and innovation. The change of the concept of individual needs and choices will not only exert great impact on the ideas of education, but it will also bring fundamental changes to the Chinese society. These new ideas are the product of the new market economy in China, and in turn they may promote the development of the Chinese market economy.

Second, Chinese higher education has long faced a contradiction between insufficient financial resources and an increasing size of the applicant pool. On the one hand, the economic development of the country faces a severe shortage of qualified manpower, and on the other hand, the State is unable to significantly increase funding to higher education. The tuition reform has provided a means of diversifying the funding structure in Chinese higher education and lightening the pressure of the funding shortage in Chinese higher education. This may, in turn, invigorate the development of Chinese higher education.

Third, the former free tuition system in higher education ensured that excellent rural senior high school graduates can enter universities and colleges. In the past, the farmers knew that if their children had an excellent academic performance in senior high schools, they would have the opportunity to enter colleges. Therefore, they tried hard to help their children to finish primary and secondary education. Now, if there 
is only a slim chance or even no hope for their children to enter higher education institutions, they may not spend so much on their children's secondary education. For the poor Chinese farmers, the fees, textbooks and other expenses for secondary education were already a great financial burden on them. In this sense, the tuition reform in higher education may well exert a negative influence on the secondary education at the senior high school level in the rural areas. In turn, there are enough similar reasons to worry about the same negative influence on the compulsory education in primary and junior high school level in the rural areas. In fact, the dropout is already a serious problem in rural junior high schools. The 1994 statistics show that the dropout rate of junior high schools in the rural areas is as high as 8.03 percent ( $W u, 1995)$.

\section{CONCLUDING REMARKS}

The above analyses show that the tuition reform in Chinese higher education is the result of the overall economic reform in China. The "educational system everywhere must change continuously to adapt to the major changes taking place in their economic, technological, social, cultural, and political environment" (Coombs and Hallak, 1987, p.97). The tuition reform breaks up the old, mono-funding structure in Chinese higher education, and provides a new funding channel for universities and colleges, which will financially invigorate the development of Chinese higher education. According to the practical conditions in China, the decision of abolishing the free tuition system in higher education institutions is reasonable for both the State and the individual citizens. Since the rural residents' per-capita income is far below the urban residents, and there are a considerable number of poor and exceptionally poor students in the universities and colleges, appropriate policies should be made to ensure that the qualified poor students have equal opportunity to enter universities and colleges, and to complete their studies. Other reforms in higher education, such as the adoption of the credit system, curriculum reform and the reform of the whole higher education administration system, should be kept in step with the implementation of the new tuition system, so that the installation of the new system can be carried out smoothly and successfully. Although the tuition reform may have some negative impacts on the secondary and compulsory education in the rural areas, the idea of free job selection has the potential of giving the Chinese youth more enthusiasm and making them more motivated as they 
undertake studies in higher education institutions. This will, in turn, bring about wealth and progress to the whole society.

\section{ACKNOWLEDGMENTS:}

The author wishes to thank Dr. Keith Walker for his encouragement and valuable suggestions, Dr. Kevin Wilson for his sincere help in revising the manuscript, and Ms Patricia Gorius for her helpful advice on the second draft. The author is also grateful to the two anonymous reviewers for their constructive comments.

\section{NOTES}

1. The current exchange rate: I US dollar $=8.3$ yuan (RMB).

2. Jiang's case evoked great concern in the society. The Education Commission of Guangdong Province decided to give him a tuition waiver. With the tuition waiver and other monetary donations from some businesses and individuals, Jiang returned to the university on September 20, 1995.

\section{REFERENCES}

An, J. (1994). One stone disturbs the water: Debates on higher education's charging for tuition (Gaoxiao Shoufei Yishi Qianlang). China Today (Chinese ed.), 43(11), 13-16.

Carnegie Commission on Higher Education. (1973). Higher education: Who pays? who benefits? who should pay? Hightstown, NJ: McGraw-Hill Book Company.

Chen, Q. (1993). Constitution amended to advance a market economy. Beijing Review, 36(17), 14-16.

Cheng. K. (1994). Young adults in a changing socialist society: Post-compulsory education in China. Comparative Education, 30(1), 63-73.

China's Scholars Abroad. (February 9, 1996). By 2000, how much will it cost a university student? (2000 Nian Yige Daxuesheng Yao Duoshao Qian?). China's Scholars Abroad [On-line], No. 56. http://www.chisa.edu.cn/

Coombs, P.H., \& Hallak, J. (1987). Cost analysis in education: A tool for policy and planning. Washington, DC: Johns Hopkins University Press.

Cui. L. (1993). New target for educational reform. Beijing Review, 36(22), 17.

Facts \& Figures. Beijing Review, 1995 38(2), 18.

Gao, S. (1994). Market economy and the labor force market. Beijing Review. 37(1), 14-16.

Guangming Daily. (December 28, 1993). Tuition fees haze farmers. In Beijing Review, 37(11), 31, 1994.

Hayhoe, R. (1989). China's universities and the open door. New York: M.E.Sharpe. 
Law. W. (1995). The role of the state in higher education reform: Mainland China and Taiwan. Comparative Education Review, 39(3), 322-355.

Ling, B. (1993). Tuition reform for higher education. Beijing Review, 36(29), 18-19.

Ma. B. (1992). Training China's future generations. Beijing Review. 35(34), 12 22.

More college students pay their own tuition. Beijing Review, 1992, 35(33), 6-7. Rai, S. (1991). Resistance and reaction: University politics in post-Mao China. New York: St. Marin's Press.

Socialist market economy: A new term in reform. Beijing Review, 1992 35(35). 7.

UNESCO. (1993). World education report. Paris, France: UNESCO.

Wu, W., \& Yang, H. (1989). Comparative pedagogy (Bijiao Jiaoyu Xue). Beijing. China: People's Education Publishing House.

Wu, Y. (September 23, 1995). A new look in the universal education (Puji Jiaoyu Huanran Yixin). People's Daily (Overseas ed.), p.3.

Xu, L. (March 15, 1996). Shanghai will abolish the "double track" system in higher education enrollment (Shanghai Quanmian Shishi Gaoxiao Zhaosheng "Binggui" Gaige). China's Scholars Abroad [On-line], No. 61.

Yang. D. (February. 1993). Our country should actively and steadily develop private universities (Woguo Ying Jiji Wendingde Fazhan Minban Daxue). Chinese Higher Education Research (Chinese ed.), p.11.

Yin, H., \& Bi, Q. (October 19, 1995). The state takes measures to sponsor poor university students (Guojia Caiqu Cuoshi Zizhu Kunnan Daxuesheng). People's Daily (Overseas ed.). p.3.

Yin, Q., \& White, G. (1994). The marketisation of Chinese higher education: A critical assessment. Comparative Education, 30(3), 217-237.

Zhen. S. (October 9, 1995). Jiang Yongtao: Everybody helps you realize your university dream (Jiang Yongtao: Zhongren Yuan $\mathrm{Ni}$ Shangxue Meng). People's Daily (Overseas ed.), p.3.

Zhou. Y. (1995). Tuition: Public to invest more capital in education. Beijing Review, 38(39), 15-17. 